\title{
ANALISIS EFEKTIVITAS DAN KONTRIBUSI PAJAK DAERAH TERHADAP PENDAPATAN ASLI DAERAH KABUPATEN KENDAL TAHUN 2014-2018
}

\author{
Deni Ariyanti dan Resi Yudhaningsih, SE., M.Si., Akt \\ Jurusan Akuntansi Program Studi Akuntansi Politeknik Negeri Semarang \\ Jl. Prof. Sudarto, SH Tembalang Semarang 50275 \\ Deniariyanti95@gmail.com; asrina_yudha@yahoo.co.id
}

\begin{abstract}
This research was conducted to find out how much the effectiveness and contribution of regional taxes on Regional Original Revenue (PAD), as well as to know how the relationship between local taxes and Kendal Regency Regional Revenue (PAD). Data collection methods used are interviews and documentation. The writing method used is description and exposition. The result of the discussion is that the level of local tax effectiveness is very effective with an average of $126.49 \%$, the criteria for regional tax contribution to regional original income are quite good with an average of $30.47 \%$, the results of regression analysis show positive results which means the growth in number Regional Tax revenues will result in the growth of Regional Original Income, and the results of the correlation analysis show that the regional tax on Kendal District Original Revenue (PAD) has a very strong relationship with a coefficient $r$ of 0.89 so that if the local tax increases then the Local Revenue Kendal Regency will alsoincrease.
\end{abstract}

Keywords: Regional Taxes, Regional Original Revenue, Effectiveness, and Contributions

\begin{abstract}
Abstrak:Penelitian ini dilakukan untuk mengetahui berapa besar efektivitas dan kontribusi pajak daerah terhadap Pendapatan Asli Daerah (PAD), serta mengetahui hubungan antara pajak daerah dengan Pendapatan Asli Daerah (PAD) Kabupaten Kendal. Metode pengumpulan data yang digunakan yaitu wawancara dan dokumentasi. Metode penulisan yang digunakan yaitu deskripsi dan eksposisi. Hasil dari pembahasan yaitu tingkat efektivitas pajak daerah sangat efektif dengan rata-rata sebesar $126,49 \%$, kriteria kontribusi pajak daerah terhadap pendapatan asli daerah cukup baik dengan rata rata sebesar 30,47\%, hasil dari analisis regresi menunjukan hasil yang positif artinya bertumbuhnya jumlah penerimaan Pajak Daerah akan mengakibatkan bertumbuhnya Pendapatan Asli Daerah, dan hasil dari analisis korelasi menunjukan bahwa pajak daerah terhadap Pendapatan Asli Daerah (PAD) Kabupaten Kendal memiliki hubungan yang sangat kuat dengan koefisien $\mathrm{r}$ sebesar 0,89 sehingga apabila pajak daerah mengalami kenaikkan maka Pendapatan Asli Daerah Kabupaten Kendal juga akan mengalami kenaikan.
\end{abstract}

Kata Kunci: Pajak Daerah, Pendapatan Asli Daerah, Efektivitas, dan Kontribusi 


\section{PENDAHULUAN}

Dijalankannya otonomi daerah merupakan salah satu bentuk dari desentralisasi pemerintahan. Otonomi daerah merupakan hak yang diperoleh dari pemerintah pusat. Dengan otonomi daerah diharapkan daerah dapat memiliki inisiatif untuk menyusun dan mengimplementasikan kebijakan daerah masing-masing, membuat peraturan daerah (PERDA) dan dapat menggali sumber - sumber keuangan yang diperoleh dari daerah tersebut. Salah satu sumber keuangan milik daerah adalah Pendapatan Asli Daerah(PAD).

Menurut Undang-undang Nomor 33 Tahun 2004 tentang Perimbangan Keuangan antara Pemerintah Pusat dan Pemerintah Daerah Pasal 1 angka 18 bahwa Pendapatan Asli Daerah, selanjutnya disebut PAD adalah pendapatan yang diperoleh daerah yang dipungut berdasarkan peraturan daerah sesuai dengan peraturan perundang-undangan yang berlaku. Undang-undang tersebut dalam Bab II Pasal 3 Ayat 1 juga menyebutkan bahwa PAD bertujuan memberikan kewenangan kepada Pemerintah Daerah untuk mendanai pelaksanaan otonomi daerah sesuai dengan potensi daerah sebagai perwujudan desentralisasi. Sumber keuangan yang berasal dari Pendapatan Asli Daerah (PAD) lebih penting dibandingkan dengan pendapatan lain daerah. Hal ini dikarenakan Pendapatan Asli Daerah dapat digunakan sesuai dengan keinginan dan inisiatif daerah tersebut, sedangkan bentuk dari pemberian pemerintah (non PAD) sifat penggunaannya lebih terikat (tidak bebas). Salah satu sumber penerimaan daerah yaitu pajakdaerah.

"Pajak daerah merupakan kontribusi wajib kepada daerah yang terutang oleh wajib pajak orang pribadi atau badan yang bersifat memaksa berdasarkan Undang Undang, dengan tidak mendapat imbalan secara langsung dan digunakan untuk keperluan daerah bagi sebesar - besarnya kemakmuran rakyat." (Mardiasmo, 2018:14). Pajak daerah terbagi menjadi dua, yaitu Pajak Provinsi danPajakKabupaten/Kota.PajakProv insimeliputiPajakKendaraanBermot or Bea Balik Nama Kendaraan Bermotor, Pajak Bahan Bakar Kendaraan Bermotor, Pajak Air Permukaan, dan Pajak Rokok. Pajak Kabupaten/Kota meliputi Pajak Hotel, Pajak Restoran, Pajak Hiburan, Pajak Reklame, Pajak Penerangan Jalan, Pajak parkir, Pajak Air Tanah, Pajak Sarang Burung Walet, Pajak Bumi dan Bangunan Perdesaan dan Perkotaan, serta Bea Perolehan Hak Atas Tanah dan Bangunan.

Kabupaten Kendal memiliki potensi Sumber Daya Manusia (SDM) dan Sumber Daya Alam (SDA) yang sangat menunjang bagi kelangsungan hidup dan pertumbuhan daerah, baik dari sektor industri maupun non industri. Adanya Kawasan Industri Kendal (KIK) menjadi tumpuan untuk mendorong perekonomian Kabupaten Kendal. Kawasan ini merupakan hasil kerja sama dua developer besar di Asia Tenggara hingga tahun 2019 sudah ada 50 perusahaan yang menjadi investor di Kawasan Industri Kendal. Kabupaten Kendal juga mempunyai berbagai macam objek wisata seperti Pantai Cahaya, Pemandian Air Panas Gonohajo dan Tirta Nusantara merupakan contoh objek wisata yang terkenal di Kabupaten Kendal. Dengan adanya potensi tersebut Badan Keuangan Daerah (BAKEUDA) Kabupaten Kendal dapat mengoptimalkan pajak daerah, sebagai salah satu Penerimaan Daerah Kabupaten Kendal. Untuk mengoptimalkan jumlah pendapatan yang akan diterima, maka perlu diketahui potensi-potensi yang dapat menambah pendapatan dan juga bagaimana BAKEUDA menyusun target penerimaan pendapatan. 
Sehingga perlu menerapkan prinsip efektivitas yang didapatkan dari realisasi yang diterima berdasarkan target yang sudahditetapkan.

\section{METODE}

Jenis data yang digunakan dalam penulisan ini adalah data sekunder berupa data Target dan Realisasi penerimaan Pendapatan Asli Daerah pada BAKEUDA Kabupaten Kendal tahun 2014 2018.

Ada pun metode pengumpulan data yang digunakan adalah menggunakan metode wawancara melalui tanya jawab kepada salah satu pegawai BAKEUDA di bidang pendapatan mengenai kendala atau hambatan dalam pemungutan Pajak Daerah Kabupaten Kendal serta metode dokumenter berupa target dan realisasi Pendapatan Daerah Kabupaten Kendal tahun 2014-2018.

\section{HASIL DAN PEMBAHASAN}

Jenis Pajak Daerah Kabupaten Kendal menurut Peraturan Daerah Kabupaten Kendal Nomor 11 Tahun 2011 tentang Pajak Daerah meliputi: (a)Pajak Hotel ; (b)Pajak Restoran; (c)Pajak Hiburan; (d)PajakReklame; (e)Pajak Penerangan Jalan; (f)Pajak Mineral Bukan Logam dan Batuan; (g)Pajak Parkir; (h)Pajak Air Tanah; (i)Pajak Sarang Burung Walet; (j)Pajak Bumi dan Bangunan Perdesaan dan Perkotaan; (k)Bea Perolehan Hak Atas Tanah dan Bangunan.

Berikut adalah Target dan Realisasi Pajak Daerah Kabupaten Kendal tahun 20142018 yang dapat dilihat pada Tabel 1 halaman berikutnya.

\section{AnalisisEfektivitas}

Penerimaan pajak daerah Kabupaten Kendal dari tahun 20142018 mengalami peningkatan. Namun pada kenyataanya sistim pemungutan pajak di Kabupaten Kendal masih kurang efektif dikarenakan banyaknya pembayaran Pajak Bumi dan Bangunan yang belum masuk ke Kas Daerah, banyaknya pengusaha kena pajak yang tidak melaporkan omsetnya secara riil dan tingkat kesadaran masyarakat untuk membayar pajak yang masih kurang. Jika sistem pemungutan Pajak Daerah menjadi efektif maka pendapatan Pajak Daerah di Kabupaten Kendal juga akan lebih maksimal sehingga akan berpengaruh untuk meningkatan Pendapatan Asli Daerah di Kabupaten Kendal. Untuk mengoptimalkan jumlah pendapatan yang diterima maka perlu menerapkan prinsip efektivitas yang didapat dari realisasi berdasarkan target yang telah ditetapkan.

Menurut Kamus Besar Bahasa Indonesia, kata efektif mempunyai arti efek, pengaruh, akibat atau dapat membawa hasil. Jadi, efektivitas adalah keaktifan, daya guna, adanya kesesuaian dalam suatu kegiatan orang yang melaksanakan tugas dengan sasaran yang dituju. Analisis efektivitas bertujuan untuk mengatahui seberapa besar tingkat efektivitas pajak daerah terhadap Pendapatan Asli Daerah (PAD).

Tingkat Efektivitas Pajak Daerah Kabupaten Kendal dapat dihitung dengan cara membandingkan antara realisasi dengan target penerimaan pajak daerah. Hasil dari perhitungan ini menunjukan seberapa besar rasio efektivitas pajak daerah Kabupaten Kendal yang dinyatakan dalam bentuk porsentase. Menurut Mahmudi (2016:142), efektivitas Pajak Daerah, dapat dihitung dengan cara:

Efektifitas Pajak Daerah = Realisasi Penerimaan Pajak Daerah x $100 \%$

Target Penerimaan Pajak Daerah 


\section{JURNAL AKTUAL AKUNTANSI KEUANGAN BISNIS TERAPAN/VOL. 3, NO 1, MEI 2020 \\ ISSN: 2622-6529}

e ISSN: 2655-1306

Tabel 1

Target dan Realisasi Penerimaan Pajak Daerah Kabupaten Kendal Tahun 2014-2018

\begin{tabular}{|c|c|c|c|c|c|c|c|c|c|c|}
\hline \multirow{2}{*}{$\begin{array}{c}\text { Jenis } \\
\text { Penerimaan }\end{array}$} & \multicolumn{2}{|c|}{2014} & \multicolumn{2}{|c|}{2015} & \multicolumn{2}{|c|}{2016} & \multicolumn{2}{|c|}{2017} & \multicolumn{2}{|c|}{2018} \\
\hline & $\begin{array}{c}\text { Target } \\
(\mathrm{Rp})\end{array}$ & $\begin{array}{l}\text { Realisasi } \\
\text { (Rp) }\end{array}$ & $\begin{array}{c}\text { Target } \\
(\mathrm{Rp})\end{array}$ & $\begin{array}{l}\text { Realisasi } \\
\text { (Rp) }\end{array}$ & $\begin{array}{c}\text { Target } \\
(\mathrm{Rp})\end{array}$ & $\begin{array}{l}\text { Realisasi } \\
\text { (Rp) }\end{array}$ & $\begin{array}{c}\text { Target } \\
\text { (Rp) }\end{array}$ & $\begin{array}{l}\text { Realisasi } \\
\text { (Rp) }\end{array}$ & $\begin{array}{c}\text { Target } \\
(\mathrm{Rp})\end{array}$ & $\begin{array}{l}\text { Realisasi } \\
\text { (Rp) }\end{array}$ \\
\hline Pajak Hotel & 55.000 .000 .00 & 54.559 .000 .00 & 55.000 .000 .00 & 77.072 .000 .00 & 70.000 .000 .00 & 96.532 .500 .00 & 125.000 .000 .00 & 141.691 .171 .00 & 160.000 .000 .00 & 168.176.467.00 \\
\hline Pajak Restoran & 1.452 .681 .550 .00 & 1.570 .800 .273 .00 & $1,290,338,500,00$ & 2.175 .598 .714 .00 & 1.890 .000 .000 .00 & 2.408 .032 .927 .00 & $2,250,000,000,00$ & 3.122 .881 .994 .00 & 3.250 .000 .000 .00 & 5.471 .528 .915 .00 \\
\hline Pajak Hiburan & 75.000 .000 .00 & 74.340 .000 .00 & 105.000 .000 .00 & 154.015 .000 .00 & 125.000 .000 .00 & 131.635 .000 .00 & 140.000 .000 .00 & 226.127 .800 .00 & 200.000 .000 .00 & 252.652 .300 .00 \\
\hline Pajak Reklame & 900.000 .000 .00 & 950.805 .400 .00 & 901.000 .000 .00 & 1.050 .125 .620 .00 & 990.000 .000 .00 & 1.308 .670 .600 .00 & 1.360 .752 .000 .00 & 1.537.140.800.00 & 1.750 .000 .000 .00 & 1.781 .254 .200 .00 \\
\hline $\begin{array}{l}\text { Pajak } \\
\text { Penerangan Jalan }\end{array}$ & 27.417 .489 .240 .00 & 34.030 .023 .973 .00 & 35.621 .316 .800 .00 & 39.371.079.078.00 & 37.510 .000 .000 .00 & 39.441 .805 .569 .00 & 44.000 .550 .000 .00 & 47.359.331.126.00 & 50.572 .350 .000 .00 & 51.899.507.598.00 \\
\hline $\begin{array}{l}\text { Pajak Mineral } \\
\text { Bukan Logam } \\
\text { dan Batuan }\end{array}$ & 600.000 .000 .00 & 436.786 .900 .00 & 450.000 .000 .00 & 387.290 .100 .00 & 500.000 .000 .00 & 743.471 .400 .00 & 600.000 .000 .00 & 971.806 .500 .00 & 800.000 .000 .00 & 805.827 .400 .00 \\
\hline Pajak Parkir & 7.000 .000 .00 & 1.250 .000 .00 & 1.250 .000 .00 & 1.150 .000 .00 & 3.000 .000 .00 & 4.150 .000 .00 & 6.000 .000 .00 & 25.271 .500 .00 & 70.000 .000 .00 & 79.470 .000 .00 \\
\hline Pajak Air Tanah & 450.000 .000 .00 & 1.104 .787 .900 .00 & 1.110 .787 .900 .00 & 1.249 .139 .300 .00 & 925.000 .000 .00 & 1.078 .922 .500 .00 & 850.000 .000 .00 & 1.055 .356 .300 .00 & 1.190 .000 .000 .00 & 1.334 .844 .000 .00 \\
\hline $\begin{array}{l}\text { Pajak Sarang } \\
\text { BurungWalet }\end{array}$ & 30.000 .000 .00 & 25.665.000.00 & 25.665 .000 .00 & 21.040 .000 .00 & 20.000 .000 .00 & 22.625 .000 .00 & 25.000 .000 .00 & 29.174 .000 .00 & 25.000 .000 .00 & 26.175.000.00 \\
\hline $\begin{array}{l}\text { Pajak Bumi dan } \\
\text { Bangunan }\end{array}$ & 16.000 .000 .000 .00 & 15.569 .254 .696 .00 & 15.569254 .696 .00 & 13.907.137.665.00 & 18.000.000.000.00 & 15.241 .220 .234 .00 & 16.000 .000 .000 .00 & 17.797 .002 .224 .00 & 20.563.000.000.00 & 21.222 .445 .542 .00 \\
\hline Pajak BPHTB & 5.150 .000 .000 .00 & 7.052 .800 .576 .00 & 7.052 .800 .576 .00 & 11.892 .241 .094 .00 & 10.000 .000 .000 .00 & 24.355 .575 .221 .00 & 22.500 .000 .000 .00 & 37.126 .046 .163 .00 & 34.000 .000 .000 .00 & 36.930 .862 .772 .00 \\
\hline PAJAK DAERAH & 52.137 .170 .790 .00 & 60.871 .073 .718 .00 & 62.182 .413 .427 .00 & 70.285 .888 .571 .00 & 70.033 .000 .000 .00 & 84.832 .640 .951 .00 & 87.875 .302 .000 .00 & 109.391.829.578.00 & 112.580 .350 .000 .00 & 119.981 .744 .194 .00 \\
\hline
\end{tabular}

Sumber: Badan Keuangan Daerah Kabupaten Kendal, 2019 
Adapun rincian kriteria efektivitas sebagaimana dapat dilihat pada

Tabel 2 sebagai berikut:

Tabel 2

Klasifikasi Kriteria Efektivitas

\begin{tabular}{cl}
\hline Prosentase Kinerja Keuangan & Kriteria \\
\hline$>100 \%$ & Sangat Efektif \\
\hline $90 \%-100 \%$ & Efektif \\
\hline $80 \%-90 \%$ & Cukup Efektif \\
\hline $60 \%-80 \%$ & Kurang Efektif \\
\hline$<60 \%$ & Tidak Efektif \\
\hline
\end{tabular}

Sumber : Depdagri, Permendagri Nomor 690.900.327, Tahun 1996

Kemampuan daerah dalam menggambarkan kemampuan daerah menjalankan tugas dikategorikan efektif apabila rasio yang dihasilkan mencapai minimal sebesar $90 \%$. Semakin tinggi rasio efektivitas yang baik. Berikut adalah efektivitas penerimaan jenis-jenis pajak daerah Kabupaten Kendal yang dapat dilihat pada Tabel 3.

Tabel 3

Efektivitas Penerimaan Jenis-Jenis Pajak Daerah Kabupaten Kendal Tahun 20142018

\begin{tabular}{|c|c|c|c|c|c|c|}
\hline \multirow[t]{2}{*}{ Jenis Penerimaan } & \multicolumn{6}{|c|}{ Efektivitas (\%) } \\
\hline & $\begin{array}{r}\text { Tahun } \\
2014 \\
\end{array}$ & $\begin{array}{l}\text { Tahun } \\
2015\end{array}$ & $\begin{array}{r}\text { Tahun } \\
2016 \\
\end{array}$ & $\begin{array}{r}\text { Tahun } \\
2017 \\
\end{array}$ & $\begin{array}{l}\text { Tahun } \\
2018\end{array}$ & $\begin{array}{l}\text { Rata-Rata } \\
\text { (\%) }\end{array}$ \\
\hline Pajak Hotel & 99.19 & 140.13 & 137.90 & 113.35 & 105.11 & 121.31 \\
\hline Pajak Restoran & 108.13 & 168.60 & 127.40 & 128.79 & 168.35 & 140.25 \\
\hline Pajak Hiburan & 99.12 & 146.68 & 105.30 & 161.51 & 126.32 & 127.78 \\
\hline Pajak Reklame & 105.64 & 116.55 & 132.18 & 112.96 & 101.78 & 113.82 \\
\hline $\begin{array}{l}\text { Pajak Penerangan } \\
\text { Jalan }\end{array}$ & 124.11 & 110.52 & 105.15 & 107.63 & 102.62 & 110.00 \\
\hline $\begin{array}{l}\text { Pajak Mineral Bukan } \\
\text { Logam dan Batuan }\end{array}$ & 72.79 & 86.06 & 148.69 & 161.96 & 100.72 & 114.04 \\
\hline Pajak Parkir & 17.85 & 92.00 & 138.33 & 421.19 & 113.52 & 156.57 \\
\hline Pajak Air Tanah & 245.50 & 112.45 & 116.64 & 124.15 & 112.92 & 142.33 \\
\hline $\begin{array}{l}\text { Pajak Sarang Burung } \\
\text { Walet }\end{array}$ & 85.55 & 81.97 & 113.12 & 116.69 & 104.70 & 100.41 \\
\hline $\begin{array}{l}\text { Pajak Bumi dan } \\
\text { Bangunan }\end{array}$ & 97.30 & 89.32 & 84.67 & 111.23 & 103.20 & 97.14 \\
\hline Pajak BPHTB & 136.54 & 168.61 & 243.55 & 165.01 & 108.62 & 164.46 \\
\hline PAJAK DAERAH & 116.75 & 113.03 & 121.13 & 124.51 & 106.57 & 126.49 \\
\hline
\end{tabular}


Berdasarkan Tabel 3 penjelasan mengenai rician efektivitas komponen pajak daerah Kabupaten Kendal tahun 2014-2018 sebagai berikut:

a. Pajak Hotel

Efektivitas pajak hotel Kabupaten Kendal tahun 2014-2018 sangat efektif dengan rata-rata 121,31\%. Efektivitas pajak hotel tahun 2014 sebesar 99,19\%. Tahun 2015 sebesar 140,13\%. Tahun 2016 sebesar 137,90\%. Tahun 2017 sebesar 113,35\%. Dan tahun 2018 sebesar 105.11\%. Pada tahun 2014 efektivitas pajak hotel cukup efektif sebesar 99,19\% walaupun realisasi pajak hotel tidak mencapai target yang telah ditentukan. Sedangkan efektivitas pajak hotel dari tahun 2015-2018 sangat efektif yaitu lebih dari $100 \%$ karena realisasi penerimaan pajak hotel sudah melebihi target yang ditentukan. Hal ini berarti kemampuan BAKEUDA Kabupaten Kendal dalam mencapai target yang telah ditentukan dari tahun 2014-2018 sudah sangat baik karena selama empat tahun tersebut realisasi penerimaan pajak hotel sudah melebihi target yang ditentukan, walaupun efektivitas pajak hotel selalu mengalami penurunan dari tahun 2015-2018. Efektivitas pajak hotel mengalami penurunan disebabkan oleh naiknya target penerimaan pajak hotel setiap tahun.

\section{b. Pajak Restoran}

Efektivitas pajak restoran

Kabupaten Kendal tahun 2014-2018 sangat efektif dengan rata-rata sebesar 140,25\%. Efektivitas pajak restoran tahun 2014 sebesar 108.13\%. Tahun 2015 sebesar 168,60\%. Tahun 2016 sebesar 127,40\%. Tahun 2017 sebesar 128,79\%. Tahun 2018 sebesar $168,35 \%$. Efektivitas pajak restoran tahun 2014-2018 lebih dari 100\% karena realisasi penerimaan pajak restoran sudah melebihi target yang telah ditentukan. Hal ini berarti kemampuan BAKEUDA Kabupaten Kendal dalam mencapai target yang telah ditentukan sudah sangat baik karena selama lima tahun tersebut realisasi penerimaan pajak restoran sudah melebihi target yang ditentukan, walaupun terjadi kenaikan dan penurunan tingkat efektivitas diantara tahun 2014-2018. Efektivitas pajak restoran mengalami kenaikkan dan penurunan karena disebabkan oleh naik turunnya realisasi penerimaan Pajak tersebut.

c. Pajak Hiburan

Efektivitas pajak hiburan

Kabupaten Kendal tahun 2014-2018 sangat efektif dengan rata-rata sebesar 127,78\%. Efektivitas pajak hiburan tahun 2014 sebesar $99.12 \%$. Tahun 2015 sebesar 146.68\%. Tahun 2016 sebesar 105,30\%.Tahun 2017 sebesar 161,51\%. Tahun 2018 sebesar $126,32 \%$. Efektivitas pajak hiburan lebih dari 100\%. Hal ini berarti kemampuan BAKEUDA Kabupaten Kendal dalam mencapai target yang ditentukan dari tahun 2014- 2018 sudah sangat baik, walaupun realisasi pada tahun 2014 tidak mencapai target yang telah ditetapkan.

\section{d. Pajak Reklame}

Efektivitas pajak reklame Kabupaten Kendal tahun 2014-2018 sangat efektif dengan rata-rata sebesar 113,82\%. Efektivitas pajak reklame tahun 2014 sebesar 105,64\%. Tahun 2015 sebesar 116,55\%. Tahun 2016 sebesar $132,18 \%$. Tahun 2017 sebesar 112,96\%. Tahun 2018 sebesar $101,78 \%$. Efektivitas pajak reklame tahun 2014-2018 lebih dari 100\% karena realisasi penerimaan pajak reklame sudah melebihi target yang telah ditentukan. Hal ini berarti kemampuan BAKEUDA Kabupaten Kendal dalam mencapai target yang telah ditentukan dari tahun 20142018 sudah sangat baik karena pada tahun-tahun tersebut realisasi penerimaan pajak reklame sudah melebihi target yang ditentukan, walaupun terjadi kenaikan dan penurunan tingkat efektivitas diantara tahun 2014-2018. 
Efektivitas pajak reklame mengalami kenaikkan dan penurunan disebabkan oleh naik turunnya realisasi penerimaan pajak tersebut.

e. Pajak Penerangan Jalan

Efektivitas pajak penerangan jalan Kabupaten Kendal tahun 20142018 sangat efektif dengan rata-rata sebesar $110 \%$. Efektivitas pajak penerangan jalan tahun 2014 sebesar 124,11\%. Tahun 2015 sebesar 110,52\%. Tahun2016 sebesar 105,15\%. Tahun 2017 sebesar $107,63 \%$. Tahun 2018 sebesar 102,62\%. Efektivitas pajak penerangan jalan tahun 2014-2018 lebih dari $100 \%$ karena realisasi penerimaan pajak penerangan jalan sudah melebihi target yang telah ditentukan. Hal ini berarti kemampuan BAKEUDA Kabupaten Kendal dalam mencapai target yang telah ditentukan dari tahun 20142018 sudah sangat baik, walaupun terjadi kenaikan dan penurunan tingkat efektivitas diantara tahun 2014-2018. Efektivitas pajak penerangan jalan mengalami kenaikkan dan penurunan disebabkan oleh naik turunnya realisasi penerimaan pajak tersebut.

\section{f. Pajak Mineral Bukan Logam dan Batuan}

Efektivitas pajak mineral bukan logam dan batuan Kabupaten Kendal tahun 2014-2018 sangat efektif dengan rata-rata sebesar $114,04 \%$. Efektivitas pajak mineral bukan logam dan batuan tahun 2014 sebesar $72,79 \%$. Tahun 2015 sebesar 86,06\%. Tahun 2016 sebesar 148,69\%. Tahun 2017 sebesar 161,96\%. Tahun 2018 sebesar 100,72\%. Efektivitas pajak mineral bukan logam dan batuan lebih dari $100 \%$ karena realisasi penerimaan sudah melebihi target yang telah ditentukan. Hal ini berarti kemampuan BAKEUDA Kabupaten Kendal dalam mencapai target yang telah ditentukan dari tahun 20162018 sudah sangat baik, walaupun realisasi pada tahun 2014 dan tahun 2015 tidak mencapai target yang telah ditentukan sehingga terjadi penurunan tingkat efektivitas yang signifikan pada tahun tersebut. Efektivitas pajak mineral bukan logam dan batuan mengalami kenaikkan dan penurunan disebabkan oleh naik turunnya realisasi penerimaan pajak tersebut.

\section{g. Pajak Parkir}

Efektivitas pajak parkir Kabupaten Kendal tahun 2014-2018 sangat efektif dengan rata-rata sebesar 156,57\%. Efektivitas pajak parkir tahun 2014 sebesar 17,85\%. Tahun 2015 sebesar 92\%. Tahun 2016 sebesar 138.33\%. Tahun 2017 sebesar 421.19\%. Tahun 2018 sebesar $113,52 \%$. Efektivitas pajak parkir tahun 2016-2018 lebih dari 100\% karena realisasi penerimaan pajak parkir sudah melebihi target yang telah ditentukan. Hal ini berarti kemampuan BAKEUDA Kabupaten Kendal dalam mencapai target yang telah ditentukan dari tahun 20162018 sudah sangat baik, walaupun realisasi penerimaan pajak parkir pada tahun 2014 dan tahun 2015 tidak mencapai target sehingga terjadi penurunan tingkat efektivitas yang signifikan pada tahun tersebut. Efektivitas pajak parkir mengalami kenaikkan dan penurunan disebabkan oleh naik turunnya realisasi penerimaan pajak tersebut.

\section{h. Pajak Air Tanah}

Efektivitas pajak air tanah Kabupaten Kendal tahun 2014-2018 sangat efektif dengan rata-rata sebesar 142,33\%. Efektivitas pajak air tanah tahun 2014 sebesar 245,50\%. Tahun 2015 sebesar 112,45\%. Tahun 2016 sebesar116,64\%. Tahun 2017 sebesar $124,15 \%$. Tahun 2018 sebesar $112,92 \%$. Efektivitas pajak air tanah tahun 2014-2018 lebih dari 100\% karena realisasi penerimaan pajak penerangan jalan sudah melebihi target yang telah ditentukan. Hal ini berarti kemampuan BAKEUDA Kabupaten Kendal dalam mencapai target yang telah ditentukan dari 
tahun 2014-2018 sudah sangat baik. Efektivitas pajak air tanah mengalami kenaikkan dan penurunan disebabkan oleh naik turunnya realisasi penerimaan pajak tersebut.

\section{i. Pajak Sarang Burung Walet}

Efektivitas pajak sarang burung walet Kabupaten Kendal tahun 20142018 sangat efektif dengan rata-rata sebesar 100,41\%. Efektivitas pajak Sarang Burung Walet tahun 2014 sebesar 85,55\%. Tahun 2015 sebesar $81,97 \%$. Tahun 2016 sebesar $113,12 \%$. Tahun 2017 sebesar 116,69\%. Tahun 2018 sebesar 104,70\%. Efektivitas pajak sarang burung walet tahun 2016-2018 lebih dari 100\% karena realisasi penerimaan pajak sarang burung walet sudah melebihi target yang telah ditentukan. Hal ini berarti kemampuan BAKEUDA Kabupaten Kendal dalam mencapai target yang telah ditentukan dari tahun 20162018 sudah sangat baik, walaupun realisasi penerimaan pajak sarang burung walet pada tahun 2014 dan tahun 2015 tidak mencapai target sehingga terjadi penurunan tingkat efektivitas yang signifikan pada tahun tersebut.

\section{j. Pajak Bumi danBangunan}

Efektivitas pajak bumi dan bangunan Kabupaten Kendal pada tahun 2014- 2018 efektif dengan ratarata sebesar $97,14 \%$. Efektivitas pajak bumi dan bangunantahun2014sebesar97,30\%.T ahun2015sebesar89,32\%.Tahun 2016 sebesar 84,67\%. Tahun 2017 sebesar 111,23\%. Tahun 2018 sebesar $103,20 \%$. Hal ini berarti kemampuan BAKEUDA Kabupaten Kendal dalam mencapai target yang telah ditentukan dari tahun 2017-2018 sudah sangat baik, walaupun realisasi penerimaan pajak bumi dan bangunan pada tahun 2014-2016 belum melebihi target yang telah ditentukan. Efektivitas pajak bumi dan bangunan mengalami kenaikkan yang disebabkan karena realisasi penerimaan pajak tersebut selalu meningkat dan melebihi target yang telah ditentukan.

k. Pajak Bea Perolehan Hak Atas

Tanah dan Bangunan

Efektivitas pajak bea perolehan hak atas tanah dan bangunan Kabupaten Kendal tahun 2014-2018 sangat efektif dengan rata-rata sebesar 164,46\%. Efektivitas pajak bea perolehan hak atas tanah dan bangunan tahun 2014 sebesar 136,54\%. Tahun 2015 sebesar 168,61\%. Tahun 2016 sebesar $243,55 \%$. Tahun 2017 sebesar 165,01\%. Tahun 2018 sebesar $108,62 \%$. Hal ini berarti kemampuan BAKEUDA Kabupaten Kendal dalam mencapai target yang telah ditentukan dari tahun 2014-2018 sudah sangat baik, walaupun terjadi penurunan tingkat efektivitas yang signifikan pada tahun 2017. Efektivitas pajak bea perolehan hak atas tanah dan bangunan mengalami kenaikkan dan penurunan karena disebabkan oleh naik turunnya realisasi penerimaan pajaktersebut.

Efektivitas penerimaan jenis-jenis pajak daerah tertinggi tahun 2014 adalah pajak air tanah, tahun 2015 yaitu pajak bea perolehan hak atas tanah dan bangunan, tahun 2016 yaitu pajak bea perolehan hak atas tanah dan bangunan, tahun 2017 yaitu pajak pajak parkir, tahun 2018 yaitu pajak restoran. Efektivitas komponen pajak terendah tahun 2014-2018 adalah pajak pajak bumi dan bangunan.Berikut adalah efektivitas penerimaan pajak daerah Kabupaten Kendal tahun 2014-2018 yang dapat dilihat pada Tabel 4 . 
Tabel 4

Efektivitas penerimaan Pajak Daerah Kabupaten Kendal Tahun 2014-2018

\begin{tabular}{|c|c|c|c|c|}
\hline \multirow{2}{*}{ Tahun } & Target & Realisasi & Efektivitas & \multirow[b]{2}{*}{ Kriteria } \\
\hline & $(\mathrm{Rp})$ & $(\mathrm{Rp})$ & (\%) & \\
\hline (1) & (2) & (3) & $(4)=(3):(2) \times 10$ & \\
\hline & & & 0 & \\
\hline \multirow[b]{2}{*}{2014} & \multirow[b]{2}{*}{52.137 .170 .790} & \multirow[b]{2}{*}{60.871 .073 .718} & \multirow{2}{*}{116,75} & Sangat \\
\hline & & & & Efektif \\
\hline \multirow{2}{*}{2015} & \multirow{2}{*}{62.182 .413 .472} & \multirow{2}{*}{70.285 .888 .571} & \multirow{2}{*}{113,03} & Sangat \\
\hline & & & & Efektif \\
\hline \multirow{2}{*}{2016} & \multirow{2}{*}{70.033 .000 .000} & \multirow{2}{*}{84.832 .640 .951} & \multirow{2}{*}{121,13} & Sangat \\
\hline & & & & Efektif \\
\hline \multirow{2}{*}{2017} & \multirow{2}{*}{87.857 .302 .000} & \multirow{2}{*}{109.391 .829 .578} & \multirow{2}{*}{124,51} & Sangat \\
\hline & & & & Efektif \\
\hline \multirow[b]{2}{*}{2018} & \multirow[b]{2}{*}{112.580 .350 .000} & \multirow[b]{2}{*}{119.981 .744 .194} & \multirow[b]{2}{*}{106,57} & Sangat \\
\hline & & & & Efektif \\
\hline
\end{tabular}

Sumber: Data sekunder yang diolah kembali, 2019

Berdasarkan Tabel 4 dapat diketahui bahwa perhitungan efektivitas dilakukan dengan cara membandingkan target penerimaan pajak daerah dengan realisasi penerimaan pajak daerah. Jika dilihat lebih rinci, efektivitas penerimaan jenis- jenis pajak daerah Kabupaten Kendal tahun 2014-2018 menunjukan kriteria yang berbeda, namun secara keseluruhan efektivitas penerimaan pajak daerah tersebut sangat efektif dengan ratarata sebesar 126,49\%. Efektivitas penerimaan pajak daerah tahun 2014 sebesar $116,75 \%$, tahun 2015 sebesar $113,03 \%$, tahun 2016 sebesar $121,13 \%$, tahun 2017 sebesar 124,51\% , tahun 2018 sebesar 106,57\%. Hal ini berarti bahwa BAKEUDA Kabupaten Kendal dalam merealisasikan penerimaan pajak daerah berhasil mencapai target yang telahditentukan.

\section{Analisis Kontribusi}

Penerimaan pajak daerah dan pendapatan asli daerah Kabupaten Kendal tahun 2014-2018 cenderung meningkat, oleh karena itu perlu dilakukan pengukuran kontribusi pajak daerah terhadap pendapatan asli daerah agar Pemerintah Daerah Kabupaten Kendal dapat mengoptimalkan pengelolaan Pendapatan Daerah Kabupaten Kendal. Kontribusi dalam Kamus Besar Bahasa Indonesia dapat diartikan sebagai sumbangan atau sesuatu yang diberikan secara nyata. Analisis kontribusi bertujuan untuk mengetahui seberapa besar kontribusi dari pajak daerah terhadap Pendapatan Asli Daerah(PAD).

Analisis kontribusi ini digunakan untuk mengukur berapa besar kontribusi yang disumbangkan oleh Pajak Daerah terhadap Pendapatan Asli Daerah di Kabupaten Kendal. Analisis kontribusi ini digunakan untuk mengukur sejauh mana atau seberapa besar sumbangan variabel 
yang menjadi bagian dari Pendapatan Asli Daerah. BAKEUDA Kabupaten Kendal mengelola 11 jenis Pajak Daerah yang kemudian akan diketahui bentuk penyerapan serta kontibusinya terhadap penerimaan daerah di Kabupaten Kendal, sehingga dapat diambil beberapa langkah kebijakan atas data tentang kontribusi pajak daerah tersebut.

Kontribusi Pajak Daerah terhadap Pendapatan Asli Daerah (PAD) menurut Halim, 2004 : 93 (dalam Candra : 2015), dapat dihitung dengan cara:

Kontribusi Pajak Daerah=

Jumlah Realisasi Pajak Daerahx 100\% Jumlah Realisasi Pendapatan Asli Daerah

Adapun rincian kriteria penilaian dalam Tabel 5 berikut: kontribusi sebagaimana diatur

Tabel 5

Klasifikasi Kriteria Kontribusi

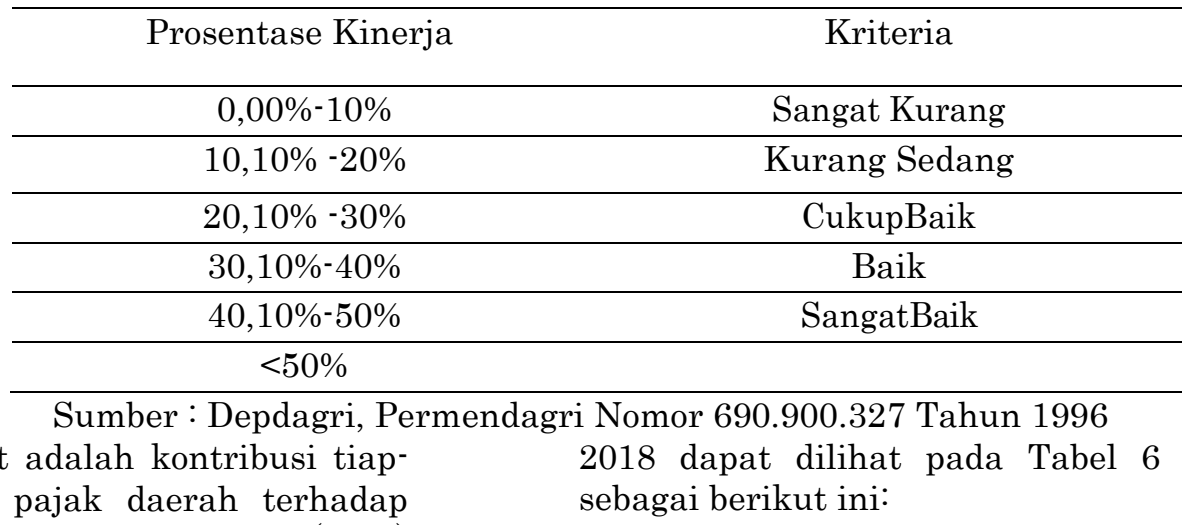
tiap jenis pajak daerah terhadap Pendapatan Asli Daerah (PAD) Kabupaten Kendal tahun 2014-

Tabel 6

Kontribusi Tiap-Tiap Jenis Pajak Daerah Terhadap Pendapatan Asli Daerah Kabupaten Kendal Tahun 2014-2018

\begin{tabular}{lllllll}
\hline Jenis-jenis Pajak Daerah & \multicolumn{6}{l}{ Kontribusi(\%) } \\
\cline { 2 - 7 } & Tahun & Tahun & Tahun & Tahun & Tahun & Rata- $^{-}$ \\
& 2014 & 2015 & 2016 & 2017 & 2018 & Rata \\
Pajak Hotel & 0.03 & 0.03 & 0.04 & 0.03 & 0.05 & 0.04 \\
Pajak Restoran & 0.73 & 0.91 & 0.91 & 0.77 & 1.63 & 0.79 \\
Pajak Hiburan & 0.04 & 0.06 & 0.05 & 0.06 & 0.08 & 0.06 \\
Pajak Reklame & 0.44 & 0.44 & 0.49 & 0.38 & 0.53 & 0.46 \\
Pajak Penerangan Jalan & 15.81 & 16.44 & 14.88 & 11.69 & 15.45 & 14.85 \\
Pajak Mineral Bukan & 0.20 & 0.16 & 0.28 & 0.24 & 0.24 & 0.22 \\
Logam dan Batuan & & & & & & \\
Pajak Parkir & 0.0006 & 0.0005 & 0.002 & 0.006 & 0.02 & 0.006 \\
Pajak Air Tanah & 0.51 & 0.52 & 0.41 & 0.26 & 0.40 & 0.42 \\
Pajak Sarang Burung & 0.01 & 0.009 & 0.009 & 0.007 & 0.008 & 0.008 \\
Walet & & & & & & \\
Pajak Bumi dan Bangunan & 7.23 & 5.81 & 5.75 & 4.39 & 6.32 & 5.9 \\
Pajak BPHTB & 3.28 & 4.96 & 9.19 & 9.17 & 11.01 & 7.52 \\
Jumlah & 28.27 & 29.34 & 32.01 & 27.00 & 35.74 & 30.47 \\
\hline
\end{tabular}

Sumber: Data sekunder yang diolah kembali, 2019 
Berdasarkan Tabel 6 penjelasan mengenai rincian kontribusi tiap-tiap jenis pajak daerah terhadap Pendapatan Asli Daerah (PAD) Kabupaten Kendal tahun 2014-2018 sebagaiberikut:

a. Pajak Hotel

Kontribusi pajak hotel terhadap Pendapatan Asli Daerah (PAD) Kabupaten Kendal tahun 2014-2018 sangat kurang dengan rata-rata sebesar $0,04 \%$. Kontribusi pajak hotel tahun 2014 sebesar 0,03\%, tahun 2015 sebesar $0,03 \%$,tahun 2016 sebesar 0,04\%, tahun 2017 sebesar 0,03\%, tahun 2018 sebesar 0,05\%. Kontribusi pajak hotel terhadap Pendapatan Asli Daerah (PAD) Kabupaten Kendal tahun 2014-2018 masuk dalam kriteria sangat kurang.

\section{b. Pajak Restoran}

Kontribusi pajak restoran terhadap Pendapatan Asli Daerah (PAD) Kabupaten Kendal tahun 2014-2018 sangat kurang dengan rata-rata sebesar $0,79 \%$. Kontribusi pajak restoran tahun 2014 sebesar $0,73 \%$, tahun 2015 sebesar 0,91\%, tahun 2016 sebesar 0,91\%, tahun 2017 sebesar 0,77\%, tahun 2018 sebesar 1,63\%. Kontribusi pajak restoran terhadap Pendapatan Asli Daerah (PAD) Kabupaten Kendal tahun 2014-2018 masuk dalam kriteria sangat kurang.

\section{c. Pajak Hiburan}

Kontribusi pajak hiburan terhadap Pendapatan Asli Daerah (PAD) Kabupaten Kendal tahun 2014-2018 sangat kurang dengan rata-rata $0,06 \%$. Kontribusi pajak hiburan tahun 2014 sebesar 0,04\%, tahun 2015 sebesar $0,06 \%$, tahun 2016 sebesar 0,05\%, tahun 2017 sebesar 0,06\%, tahun 2018 sebesar $0,08 \%$. Kontribusi pajak hiburan terhadap Pendapatan Asli Daerah (PAD) Kabupaten Kendal tahun 2014-2018 masuk dalam kriteria sangat kurang.

\section{d. Pajak Reklame}

Kontribusi pajak reklame terhadap Pendapatan Asli Daerah (PAD) Kabupaten Kendal tahun 2014-2018 sangat kurang dengan rata-rata sebesar $0,46 \%$. Kontribusi pajak reklame tahun 2014 sebesar 0,44\%, tahun 2015 sebesar 0,44\%, tahun 2016 sebesar 0,49\%, tahun 2017 sebesar 0,38\%, tahun 2018 sebesar 0,53\%. Kontribusi pajak reklame terhadap Pendapatan Asli Daerah(PAD) Kabupaten Kendal tahun 2014-2018 masuk dalam kriteria sangat kurang.

e. Pajak Penerangan Jalan

Kontribusi pajak penerangan jalan terhadap Pendapatan Asli Daerah (PAD) Kabupaten Kendal tahun 2014-2018 dengan rata-rata sebesar 14,85\%. Kontribusi pajak penerangan jalan tahun 2014 sebesar $15,81 \%$, tahun 2015 sebesar $16,44 \%$, tahun 2016 sebesar $14,88 \%$, tahun 2017 sebesar 11,69\%, tahun 2018 sebesar 15,45\%. Kontribusi pajak penerangan jalan terhadap Pendapatan Asli Daerah (PAD) Kabupaten Kendal tahun 2014-2018 masuk dalam kriteria kurang.

f. Pajak Mineral Bukan Logam dan Batuan

Kontribusi pajak mineral bukan logam dan batuan terhadap Pendapatan Asli Daerah (PAD) Kabupaten Kendal tahun 2014-2018 sangat kurang dengan rata-rata sebesar 0,22\%. Kontribusi pajak mineral bukan logam dan batuan tahun 2014 sebesar 0,20\%, tahun 2015 sebesar $0,16 \%$, tahun 2016 sebesar 0,28\%, tahun 2017 sebesar 0,24\%, tahun 2018 sebesar 0,24\%. Kontribusi pajak mineral bukan logam dan batuan terhadap Pendapatan Asli Daerah (PAD) Kabupaten Kendal tahun 2014-2018 masuk dalam kriteria sangat kurang.

\section{g. Pajak Parkir}

Kontribusi pajak parkir terhadap Pendapatan Asli Daerah (PAD) Kabupaten Kendal tahun 2014-201 sangat kurang dengan rata-rata sebesar $0,006 \%$. Kontribusi pajak 
parkir tahun 2014 sebesar 0,0006\%, tahun 2015 sebesar $0,0005 \%$, tahun 2016 sebesar $0,002 \%$, tahun 2017 sebesar 0,006\%, tahun 2018 sebesar $0,02 \%$. Kontribusi pajak parkir terhadap Pendapatan Asli Daerah (PAD) Kabupaten Kendal tahun 2014-2018 masuk dalam kriteria sangatkurang.

h. Pajak Air Tanah

Kontribusi pajak air tanah terhadap Pendapatan Asli Daerah (PAD) Kabupaten Kendal tahun 2014-2018 sangat kurang dengan rata-rata sebesar $0,42 \%$. Kontribusi pajak air tanah tahun 2014 sebesar $0,51 \%$,tahun 2015 sebesar $0,52 \%$, tahun 2016 sebesar $0,41 \%$,tahun 2017 sebesar 0,26\%, tahun 2018 sebesar $0,40 \%$. Kontribusi pajak air tanah terhadap Pendapatan Asli Daerah (PAD) Kabupaten Kendal tahun 2014-2018 masuk dalam kriteria sangat kurang.

i. Pajak Sarang Burung Walet

Kontribusi pajak sarang burung walet terhadap Pendapatan Asli Daerah (PAD) Kabupaten Kendal tahun 2014-2018 sangat kurang dengan rata-rata sebesar $0,008 \%$. Kontribusi pajak sarang burung walet tahun 2014 sebesar $0,01 \%$, tahun 2015 sebesar 0,009\%, tahun 2016 sebesar 0,009\%, tahun 2017 sebesar 0,007\%, tahun 2018 sebesar $0,008 \%$. Kontribusi pajak sarang burung walet terhadap Pendapatan Asli Daerah (PAD) Kabupaten Kendal tahun 2014-2018 masuk dalam kriteria sangatkurang.

j. Pajak Bumi dan Bangunan

Kontribusi pajak bumi dan bangunan terhadap Pendapatan Asli Daerah (PAD) Kabupaten Kendal tahun 2014-2018 sangat kurang dengan rata-rata sebesar $5,9 \%$. Kontribusi pajak bumi dan bangunan tahun 2014 sebesar $7,23 \%$, tahun 2015 sebesar 5,81\%, tahun 2016 sebesar 5,75\%, tahun 2017 sebesar $4,39 \%$, tahun 2018 sebesar 6,32\%.
Kontribusi pajak bumi dan bangunan terhadap Pendapatan Asli Daerah (PAD) Kabupaten Kendal tahun 2014-2018 masuk dalam kriteria sangat kurang.

k. Pajak Bea Perolehan Hak Atas Tanah dan Bangunan

Kontribusi pajak bea perolehan hak atas tanah dan bangunan terhadap Pendapatan Asli Daerah (PAD) Kabupaten Kendal tahun 2014-2018 sangat kurang dengan rata-rata sebesar 7,52\%. Kontribusi pajak bea perolehan hak atas tanah dan bangunan tahun 2014 sebesar $3,28 \%$, tahun 2015 sebesar $4,96 \%$, tahun 2016 sebesar 9,19\%, tahun 2017 sebesar 9,17\%, tahun 2018 sebesar 11,01\%. Kontribusi bea perolehan hak atas tanah dan bangunan terhadap Pendapatan Asli Daerah (PAD) Kabupaten Kendal tahun 2014-2018 masuk dalam kriteria sangat kurang.Kontribusi penerimaan Jenis-jenis pajak tertinggi tahun 2014-2018 adalah pajak penerangan jalan dan yang terendah adalah pajak parkir.

Berikut adalah kontribusi penerimaan pajak daerah terhadap PAD Kabupaten Kendal tahun 20142018 yang dapat dilihat pada Tabel 7 . 
Tabel 7 Kontribusi Pajak Daerah Terhadap Pendapatan Asli Daerah Kabupaten
Kendal Tahun 2014-2018

\begin{tabular}{ccccc}
\hline TH & Pajak Daerah & PAD & Kontribusi & \\
& $(\mathrm{Rp})$ & $(\mathrm{Rp})$ & $(\%)$ & Kriteria \\
$(1)$ & $(2)$ & $(3)$ & $(4)=(2):(3) \mathrm{X} 100$ & \\
\hline $\mathbf{2 0 1 4}$ & 60.871 .073 .718 & 215.294 .086 .780 & 28.27 & Sedang \\
2015 & 70.285 .888 .571 & 239.564 .403 .981 & 29.34 & Sedang \\
& & & & Cukup \\
2016 & 84.832 .640 .951 & 265.074 .406 .548 & 32.01 & Baik \\
& & & & Sedang \\
2017 & 109.391 .829 .578 & 404.978 .613 .972 & 27.00 & Cukup \\
& & & 35.74 & Baik \\
\hline
\end{tabular}

Sumber: Data sekunder yang diolah kembali, 2019

Berdasarkan Tabel 7 dapat diketahui bahwa perhitungan kontribusi pajak daerah terhadap pendapatan asli daerah dapat dilakukan dengan cara membandingkan antara realisasi penerimaan pajak daerah dengan realisasi penerimaan pendapatan asli daerah. Jika dilihat secara keseluruhan kontribusi pajak daerah terhadap pendapatan asli daerah tahun 2014-2018 tersebut masuk dalam kriteria cukup baik dengan rata-rata sebesar $30,47 \%$. Kontribusi pajak daerah tahun 2014 sebesar $28,27 \%$, tahun 2015 sebesar 29,27\%, tahun 2016 sebesar 32,01\%, tahun 2017 sebesar 27,00\%, tahun 2018 sebesar 35,74\%.

Kontribusi pajak daerah terhadap pendapatan asli daerah Kabupaten Kedal dari tahun 2014-2016 mengalami kenaikkan, namun pada tahun 2017 mengalami penurunan dan kontribusi pajak daerah terhadap pendapatan asli daerah tersebut mengalami kenaikkan kembali pada tahun 2018. Hal ini disebabkan oleh naik turunnya realisasi penerimaan komponen pajak daerah dan pendapatan asli daerah setiap tahunnya. Berdasarkan penjelasan tersebut dapat diketahui bahwa kontribusi pajak daerah terhadap pendapatan asli daerah Kabupaten Kedal tergolong cukup baik dan Badan Keuangan Daerah (BAKEUDA) Kabupaten Kedal sudah berhasil dalam merealisasikan penerimaan pajak daerah melebihi target yang telah ditentukan, dan target penerimaan pajak daerah tersebut selama lima tahun dari tahun 2014- 2018 selalu mengalami kenaikkan.

Dengan dinaikkannya target penerimaan pajak daerah, diharapkan Pemerintah 


\begin{abstract}
Kabupaten Kendal dapat meningkatkan dan mengembangkan potensi pajak daerah tersebut sehingga mampu memberikan kontribusi yang tinggi terhadap pendapatan asli daerah Kabupaten Kendal. Disisi lain BAKEUDA Kabupaten Kendal sebagai petugas yang melaksanakan pemungutan pajak daerah perlu mengoptimalkan kembali pemungutan pajak daerah sesuai dengan ketentuan agar wajib pajak dapat melaporkan dan menyetorkan/membayar pajak sesuai dengan keadaan yang sebenarnya, serta perlu menambah petugas untuk menagih pajak kepada wajib pajak agar wajib pajak sadar akan pentingnya membayar pajaktersebut.
\end{abstract}

\section{SIMPULAN}

a. Efektivitas Pajak Daerah Kabupaten Kendal tahun 20142018 sangat efektif. Hal ini memperlihatkan bahwa realisasi penerimaan pajak daerah Kabupaten Kendal rata-rata sudah melebihi dengan target yang telah ditetapkan. Wajib pajak sebagian besar memiliki kesadaran akan kewajibanperpajakannya.

b. Kontribusi Pajak daerah terhadap Pendapatan Asli Daerah Kabupaten Kendal tahun 2014-2018 cukup baik. Hal ini menunjukan bahwa Pemerintah Kabupaten Kendal dalam ini Badan Keuangan Daerah Kabupaten Kendal sudah cukup baik dalam mengelola, mengidentifikasi, menggali potensi dan mengoptimalkan sumber-sumber pendapatan daerah.

\section{DAFTAR PUSTAKA}

Alek dan Achmad. 2011. Bahasa Indonesia untuk Perguruan Tinggi. Jakarta: Kencana Prenanda
Bungin, Burhan. 2013. Metodologi Penelitian Sosial \& Ekonomi: Format-format Kuantitatif dan Kualitatif untuk Studi Sosiologi, Kebijakan, Publik, Komunikasi, Manajemen, dan Pemasaran. Jakarta: Kencana Prenada Media Group.

Handoko, T. H. (2011). Manajemen. Yogyakarta: BPFE UGM.

Mahmudi. 2016. Analisis Laporan Keuangan Pemerintah Daerah. Yogyakarta: Sekolah Tinggi Ilmu Manajemen YKPN

Mardiasmo. 2018. Perpajakan. Yogyakarta: ANDI OFFSET

Peraturan Daerah Kabupaten Kendal Nomor 11 Tahun 2011 tentang Pajak Daerah.

Romanda, Candra. 2015. Kontribusi dan Efektivitas Pajak Daerah Terhadap Pendapatan Asli Daerah Kabupaten Musi Banyuasin Provinsi Sumatera Selatan. Julnal Akuntansi Politeknik Sekayu (ACSY). (Online). Vol II. No I. (file:///C:/Ussers/acer/Downloads/ 93-1991-PB\%20(1).pdf,diakses 12 April 2019)

Sugiyono. 2011. Metode Penelitian Administrasi dan $R \& D$. Bandung: Alfabeta

Sugiyono. 2016. Metodelogi Penelitian Kuantitatif, Kualitatif dan $R \& D$. Bandung: Alfabeta

Undang - Undang Nomor 33 Tahun 2004 tentang Perimbangan Keuangan antara Pajak Pusat dan Daerah

Undang-undang Republik Indonesia Nomor 28 Tahun 2009 tentang Pajak Daerah dan Retribusi Daerah. 
JURNAL AKTUAL AKUNTANSI KEUANGAN BISNIS TERAPAN/VOL. 3, NO 1, MEI 2020

ISSN: 2622-6529

e ISSN: 2655-1306

Undang-Undang Republik Indonesia Nomor 23 Tahun 2014 tentang tentang Keuangan Daerah.

Pemerintahan Daerah.

Undang-undang Republik Indonesia Nomor 16 tahun 2009 tentang

Undang-undang Republik Indonesia Ketentuan Umum dan Tata Cara Nomor 32 Tahun 2004 BAB VIII Perpajakan. 